\title{
Quality assessment of commercially available Newcastle disease vaccine in Lagos
} State, Nigeria

*Ambali, H. A., ${ }^{1}$ Okolocha, E. C., ${ }^{1}$ Kabir, J. and ${ }^{2}$ Moru, N. H.

*Department of Veterinary Medicine, Faculty of Veterinary Medicine, University of Ilorin, Kwara State

${ }^{I}$ Departmentof Veterinary Public Health and Preventive Medicine, Faculty of Veterinary

Medicine, Ahmadu Bello University, Zaria

${ }^{2}$ National Animal Production Research Institute, Ahmadu Bello University, Zaria.

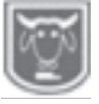

Corresponding author: ambali.hm@,unilorin.edu.ng; +2348023264769

Abstract

Newcastle disease (ND) outbreaks occur among vaccinated and non-vaccinated poultry flocks causing varying degrees of economic losses despite vigorous vaccination for the control of the disease. In this study, the qualities of vaccines available for the control of ND in poultry in Lagos State were evaluated. A total of 264 blood samples were collected from poultry flocks of the enrolled farmers and 80vials of ND vaccines were obtained from nine poultry vaccine retailers patronized by the enrolled farmers. Twenty-five vials of ND vaccines were also collected from five importers that were patronized by the poultry vaccine retailers. Five vials each of the different ND vaccines were purchased from each retailers or importers and were used as representative samples of the different ND vaccines available for sale at the time of sampling. These were subjected to both physical and serological testing using Haemagglutination test (HA), Haemagglutination-inhibition test (HI) and Enzyme-linked immunosorbent assay (ELISA). Coefficient of variance of solubility among all the vaccines ranged from $7.06 \%$ to $378.89 \%$. Vaccines obtained from retailers had mean $H A$ titres of between $0.2 \log _{2}$ and $11 \log _{2}$, while for the imported vaccines the mean HA titre was between $6 \log _{2}$ and $10.8 \log _{2}$. Two hundred and sixty-four sera were tested for $N D$ antibody, out of which 240 (90.91\%) and 262 (99.24\%) were positive for the presence of protective HI and ELISA ND antibodies respectively. From this study, lower coefficient of variance of solubility was observed in vaccines from importers than those from retailers which could indicate that vaccines are probably better stored by importers than the retailers. There should be proactive government monitoring agency at all levels of vaccine protocols.

Keywords: Poultry, Vaccine, Newcastle disease, ELISA, HI

\section{Introduction}

The poultry sector is important to the livelihood of millions of Nigerians and is a major contributor to the agricultural GDP (Ezekiel et al., 2012). In recent times, the growth in the poultry sector is encouraged to provide employment and increase the output of both meat and eggs for a rapidly growing Nigerian population (Sainsbury, 2000) despite the threat posed by avian epidemics including the recent resurgence of Avian Influenza (NVMA, 2015).
Majority of the suspected cases of Avian Influenza eventually turn out to be velogenic Newcastle Disease (ND) emphasizing the high prevalence and economic importance of the latter in Nigeria. Newcastle disease is one of the most dreaded viral diseases of poultry in Nigeria as it causes severe economic losses in domestic and wild bird populations resulting from illness, reduced egg production, immunosuppression, and death following infection with pathogenic strains 


\section{Quality assessment of commercially available Newcastle disease vaccine}

of the viruses (Okeke and Lamorde, 1988; Ibu et al., 2000). It has been speculated that ND may represent a greater burden on the world economy than any other animal viral disease (Alexander, 2003). Vaccines are available to prevent and control the disease incidence. For a vaccine to be useful it must be immunogenic and safe to use. The safety and efficacy of any vaccine need to be evaluated to justify its continued use and reliance by farmers. However, regulatory authorities routinely subject locally produced and imported vaccines to quality control as a mechanism for ensuring availability of safe and efficacious vaccines. Recommended vaccine testing protocols utilize a few methods as provided by the Office Internationale des Epizootics (OIE, 1992). Diagnostic tests are in two categories: Prescribed and Alternative. Prescribed tests are required by OIE Terrestrial Animal Health Code for the international movement of animals and animal products and are considered optimal for determining the health status of animals, while Alternative tests are those that are suitable for diagnosis of disease within a local setting. Prescribed test for ND is virus isolation, while alternative test is haemagglutination-inhibition test (HI) and Enzyme-linked immunosorbent assay (ELISA) (OIE, 2008). The use of the HI method as means of assessing the immune status of vaccinated poultry has been on the increase and provides a more practical method in assessing a vaccinated flock than any other (Phillips, 1973; Allan and Gough, 1984; Aliyu et al., 2016). In developing countries, including Nigeria, the regulatory assessment and quality assurance of vaccine is very weak; farmers are thus compelled to know the effectiveness of vaccines only after use. Outbreak of this disease occurs despite vigorous and strict vaccination programme. The availability of poor quality vaccines and presence miscellaneous unreliable vaccination programmes against ND might be the cause of the increasing rate of the disease (Aliyu et al., 2015). Although vaccination failure is said to be multifactorial including poor and/or none viable vaccines, poor administration techniques, foul play, stress etc, and hence, the need to assess the quality of the vaccine at the markets and the end users' levels. This study was carried out to assess some of the quality standards of ND vaccine that are commercially available in Lagos State, Nigeria.

\section{Methodology \\ Studyarea}

This study was carried out in Lagos State which is located in South- western Nigeria, and lies between Latitude $6^{\circ} 2^{\prime} \mathrm{N}-6^{\circ} 2 \mathrm{~N}$ and Longitude $2^{\circ} 45 \mathrm{E}-4^{\circ} 20^{\prime} \mathrm{E}$ with a land area of $3.475 \mathrm{~km}^{2}$. The State has three senatorial districts (Lagos West, Lagos East and Lagos Central) with 20 recognised Local $\mathrm{G}$ o v e r n m e $\mathrm{n} \mathrm{t} \quad$ A r e a $\mathrm{s}$ (LGAs)(http://Lagosstate.gov.ng,2014). The main vegetation types are the dry lowland rain forest and swamp forest (a combination of mangrove forest and coastal vegetation developed under brackish conditions and swamp of freshwater lagoons and estuaries) consisting wetlands, teak (Ogundele, 2012). There are poultry estates established under the auspices of Lagos State Ministry of Agriculture and Cooperative located in all-geopolitical zone of Lagos State among which are Ikorodu, Badagry, Epe, Eti Osa and Ojo.

\section{Study design}

Cross sectional study, consisting of a survey of available vaccines and use in Lagos state at the level of importers, retailers and farmers, also for serological detection of protective immune status amongst vaccinated flocks were conducted involving 42 farmers in 5 out of 20 LGAs in the state. Farmers whose birds were 


\section{Ambali, Okolocha, Kabir and Moru}

sampled and used in this study were those who obtained their vaccines from the responded surveyed importers and retailers. Sample collection

Collection of vaccines samples from retailers and importers

Information on vaccine retailers were obtained from selected farmers (the retailers they patronize), five vials each of the different ND vaccines available at the retailers' shop were purchased. A total of 80 vials of ND vaccines (1,000 doses- 25 vials, 200 doses- 25 vials and 100 doses-30 vials) were obtained from nine retailers. Information about vaccine importers were obtained from sampled retailers. The State was treated as one sampling unit, irrespective of the LGA. Twenty-five vials of ND (1,000doses-15 vials, 200 doses5vials, 100doses-5vials) vaccine were obtained from the five vaccine importers.

Blood samples collection from farms that use vaccines from the enrolled retailers and importers

Twenty-five percent of the registered farmers in each of the five LGA were randomly selected. Ten birds were randomly selected from each flock on the farm and bled. Birds of the same age housed together under the same management were regarded as a flock irrespective of the number. Blood sample was obtained through the radial vein by wing venopuncture. Five millilitres (mL) of blood were aseptically collected using sterile hypodermic $23 \mathrm{G}$ needle and $5 \mathrm{mLsyringesfrom} \mathrm{each} \mathrm{bird} \mathrm{and} \mathrm{dispensed}$ into plain sample bottle, allowed to clot and the serum was separated and stored at $20^{\circ} \mathrm{C}$ until tested.

Physical assessment of the vaccines

The physical assessment of vaccines collected was done as described by Pastoret et al. (1997). Each vial of vaccine was assessed physically by checking for the type of vaccine, if it is lyophilize or not, labelling, colour, dosage form, manufacturing date, expiry date, batch number, time of solubility (time taken by the pellet of each vial of the vaccine to dissolve completely in equal volume of normal saline) and vaccum test (the time it takes the plunger of the syringe inserted in an undiluted vial of vaccine to be pushed out) were carried out.

\section{Laboratory assessment of the vaccines}

Laboratory assessment of ND vaccines quality was carried out using serological tests (HA, HI and ELISA).

Determination of vaccine titre by haemagglutination test

The HA test was carried out as described by OIE (2012). In order to maintain equal concentration, dilution per vial was $200 \mathrm{dose} / \mathrm{ml}$, $(0.5 \mathrm{ml}$ for 100 dose vial, $1 \mathrm{ml}$ for 200 dose vial and $5 \mathrm{ml}$ for 1,000 dose vial).

Determination of antibody titre to Newcastle disease virus using enzyme linked Immunosorbent assay technique

Enzyme linked immunosorbent assay technique was carried out as recommended by the manufacturer (ID. Vet Innovative Diagnostics, France).

Determination of antibody titre to Newcastle disease using haemagglutination inhibition test

Preparation of Newcastle disease virus antigen: Newcastle Disease Virus vaccine, La Sotastrain (200 doses vial) obtained from National Veterinary Research Institute, Vom was reconstituted in $2 \mathrm{~mL}$ of Phosphate buffer solution (PBS) ( $\mathrm{pH} 7.4)$. This solution was used as antigen for the HI tests.

Preparation of one per cent red blood cells suspension: Five milliliters of blood were aseptically collected from an apparently healthy unvaccinated bird using sterile hypodermic needle and syringe and transferred into EDTA test tube, then washed (centrifuged at $3000 \mathrm{rpm}$ for five 


\section{Quality assessment of commercially available Newcastle disease vaccine}

minutes, the supernatant was discarded and then PBS were added and was centrifuged again, this was repeated three times). Thirty-nine thousand six hundred microliliters of PBS was measured into sterile container and $400 \mu 1$ of the washed $\mathrm{RBC}$ was added to get the $1 \%(\mathrm{v} / \mathrm{v})$ washed RBC.

\section{Determination of haemagglutination titre}

The haemagglutination ability (HA) titre was determined as described by OIE (2012). Twenty-five microlitres of PBS was dispensed in middle ten wells of the $\mathrm{V}$ bottom microtitre plates leaving the first and last wells empty, $25 \mu 1$ of the prepared antigen (study vaccines) was then dispensed into the first two wells in rows of A and B only of the plate. Two-fold serial dilution was then done which was followed by addition of $25 \mu \mathrm{l}$ of $1 \%(\mathrm{v} / \mathrm{v})$ chicken RBC. Haemaglutination was determined by tilting the plate and observing for presence or absence of tear shaped streaming of the RBCs. Presence of agglutination indicates positive reaction. The end point was determined by the highest titre value which is 1haemaglutinating unit (HAU).

Determination of haemagglutination inhibition test

The haemagglutination inhibition (HI) test was used for detection of the presence of antibodies against ND according to OIE (2012).

\section{Data analyses}

Data were analysed with Statistical Package for Social Science (SPSS) Version 20. Coefficient of viability was used to determine conditions of storage of the vaccines between retailers and importers. Data obtained were presented using tables and charts. Values of $p<0.05$ were considered significant.

\section{Results \\ Physical characteristics of Newcastle disease poultry vaccines sold in Lagos}

\section{State}

Physical characteristics of Newcastle disease poultry vaccines from retailers

The 80 vials of vaccine from retailers were manufactured by 16 different manufacturers.

\section{Packaging}

Forty out of the 80 vials of ND vaccine pellet were in big $(10 \mathrm{ml})$ transparent bottles with double cocking. Out of which only two (5\%)had their tablets broken. The other 40 were in small $(2 \mathrm{~mL})$ bottles, $25(62.5 \%)$ of which had double cocking, while $15(37.5 \%)$ had single cocking, 35(87.5\%) of the vaccine tablets were in transparent bottles while five $(12.5 \%)$ were in ambercolored bottles. The tablets were all in lyophilize form with only two colours blue and milky white.

\section{Labelling}

The ND vaccines labels were intact with details of manufacturing date, expiry date, batch numbers and EID (embryo infectious dose). Expiry dates had up to two years from date of manufacture for foreign vaccines and six months for locally manufactured vaccines.

\section{Solubility}

Among all the vaccines, the coefficient of variance $(\mathrm{CV})$ of solubility ranged from $7.06 \%$ to $378.89 \%$ (Table 1 ).

\section{Vacuum}

Forty vials $(50 \%)$ of the vaccines had no vacuum, while the other $40(50 \%)$ had vacuum.

Physical evaluation of Newcastle disease vaccines from importers

\section{Packaging}

Out of 25 vials of ND obtained from importers, $10(40 \%)$ were in big $(10 \mathrm{ml})$ bottle category while $15(60 \%)$ were in small $(2 \mathrm{~mL})$ bottle category. Twenty $(80 \%)$ of the vials had transparent bottles while only five $(20 \%)$ had bluish colouration. Twenty $(80 \%)$ were double cocked while five $(20 \%)$ had single cocking. They were all in freeze dried form. 


\section{Ambali, Okolocha, Kabir and Moru}

Table 1: Physical characteristics of Newcastle disease vaccines obtained from retailers in Lagos

\begin{tabular}{|c|c|c|c|c|c|c|c|}
\hline $\begin{array}{l}\text { Vaccine } \\
\text { code }\end{array}$ & $\begin{array}{l}\text { Vaccine } \\
\text { source }\end{array}$ & Batch no & $\begin{array}{c}\text { Bottle } \\
\text { Category }\end{array}$ & Dosage & Vacuum & $\begin{array}{c}\text { CV } \\
\text { Solubility } \\
(\%)\end{array}$ & $\begin{array}{l}\text { HA Titre } \\
\left(\log _{2}\right)\end{array}$ \\
\hline GSKL001A & $\mathrm{Iz}$ & 6771 & Big & 200 & Yes & 45.80 & $10 \pm 0$ \\
\hline GSKL001B & In & L5114 & Small & 100 & No & 30.76 & $9 \pm 0.89$ \\
\hline JOF001 & In & L5114 & Small & 100 & No & 12.56 & $7.4 \pm 0.49$ \\
\hline JVL001A & $\mathrm{Be}$ & L1614 & Big & 200 & Yes & 15.96 & $0.2 \pm 0.4$ \\
\hline JVL001B & Ro & B27281 & Small & 100 & No & 12.08 & $10 \pm 0.63$ \\
\hline KOP001A & NV & $22-2014$ & Big & 200 & Yes & 17.54 & $9.8 \pm 0.4$ \\
\hline KOP001B & $\mathrm{Ce}$ & 30502024 & Small & 1000 & No & 13.84 & $9.8 \pm 0.75$ \\
\hline KOP001C & In & L5114 & Small & 100 & No & 18.21 & $8.6 \pm 0.49$ \\
\hline LATL001A & $\mathrm{Ab}$ & 201410488 & Big & 1000 & No & 378.89 & $8 \pm 0$ \\
\hline LATL001B & Ro & B27281 & Small & 100 & No & 32.77 & $10.8 \pm 0.4$ \\
\hline LATL001C & NV & 24-2014 & Big & 200 & Yes & 35.05 & $11 \pm 0$ \\
\hline MVC001A & NV & $21-2014$ & Big & 200 & Yes & 15.19 & $10.8 \pm 0.4$ \\
\hline MVC001B & Iz & 6651 & Big & 1000 & Yes & 20.81 & $7.6 \pm 0.8$ \\
\hline PSL001 & Ro & B27281 & Small & 100 & No & 13.55 & $10.6 \pm 0.49$ \\
\hline SOLP001A & $\mathrm{Av}$ & LA13039 & Big & 1000 & Yes & 40.81 & $4 \pm 0$ \\
\hline SOLP001B & In & L5114 & Small & 100 & No & 7.06 & $9 \pm 1.09$ \\
\hline
\end{tabular}

\section{Labelling}

All the poultry vaccines from the same importer had the same batch number and had up to two years from date of manufacturing to expiration. Fifteen vials were in 1000 doses while 10 vials were in 100 doses.

\section{Vacuum and solubility}

The vacuum and CV of solubility obtained from the physical evaluation of ND vaccines showed that only 10 vials $(40 \%)$ had vacuum, while 15 vials $(60 \%)$ had no vacuum. The $\mathrm{CV}$ of solubility ranged from $42.67 \%$ to $92.72 \%$ (Table 2 ).

Table 2: Physical characteristics of Newcastle disease vaccines obtained from importers in Lagos state

\begin{tabular}{llllllll}
\hline $\begin{array}{l}\text { Vaccine } \\
\text { code }\end{array}$ & $\begin{array}{l}\text { Vaccine } \\
\text { source }\end{array}$ & $\begin{array}{l}\text { Batch } \\
\text { No }\end{array}$ & $\begin{array}{l}\text { Bottle } \\
\text { category }\end{array}$ & Dosage & Vacuum & $\begin{array}{l}\text { Solubility } \\
\%\end{array}$ & $\begin{array}{l}\text { HA titre } \\
\left(\log _{2}\right)\end{array}$ \\
\hline AD001 & Ce & 100701826 & Small & 1000 & No & 68.41 & $10.8 \pm 0.4$ \\
AGCL001 & Iz & 5551 & Big & 1000 & Yes & 49.92 & $10.6 \pm 0.49$ \\
ANCL001 & In & L5314 & Small & 100 & No & 47.81 & $9.2 \pm 0.75$ \\
CHML001 & Ro & B27281 & Small & 100 & No & 42.66 & $10.6 \pm 0.8$ \\
TRWL001 & Av & LA14039 & Big & 1000 & Yes & 92.72 & $6 \pm 0$ \\
\hline
\end{tabular}

\section{Evaluation of Haemagglutination Test of} Newcastle Disease Vaccines

Mean HA titres of vaccines from retailers with standard deviation was calculated and ranged from $0.2 \log _{2} \pm 0.4 \mathrm{SD}$ to $10.8 \log _{2} \pm 0$ $\mathrm{SD}$ for foreign vaccines and $9.8 \log _{2} \pm 0.4$ $\mathrm{SD}$ to $11.0 \log _{2} \pm 0 \mathrm{SD}$ for locally manufactured vaccines (Table 1). The HA mean titre levels of vaccines from the importers vaccines ranged from $6 \log _{2} \pm 0$
SD to $10.8 \log _{2} \pm 0.4 \mathrm{SD}$ (Table2).

Serum samples with Protective Antibody Titre to Newcastle Disease using Haemagglutination inhibition and Enzyme linked immunosorbent assay

Sera tested from four out of the five LGA had $100 \%$ protective antibody titre with ELISA while only that from 1 LGA had $100 \%$ protective antibody with HI (Tables 3 and 4$)$. 


\section{Quality assessment of commercially available Newcastle disease vaccine}

Out of 264 serum samples from five LGA tested with HI and ELISA, $240(90.91 \%)$ had protective antibody titre $\left(>5 \log _{2}\right)$ to
HI, while, 262(99.24\%) had protective antibody titre $\left(>5 \log _{2}\right)$ to ELISA(Table 5).

Table 3: Distribution of serum samples with protective antibody titre level to Newcastle disease in Lagos State using haemagglutination inhibition test

\begin{tabular}{lccc}
\hline $\begin{array}{l}\text { Local Government } \\
\text { Area }\end{array}$ & $\begin{array}{c}\text { No of serum } \\
\text { Samples } \\
\text { Tested }\end{array}$ & $\begin{array}{c}\text { No of samples with } \\
\text { protective antibody titre } \\
\text { level }(\%)\end{array}$ & $\begin{array}{c}\text { Non protective } \\
\text { Antibody titre level } \\
(\%)\end{array}$ \\
\hline Badagry & 92 & $83(90.2)$ & $9(9.78)$ \\
Epe & 24 & $20(83.33)$ & $4(16.67)$ \\
Etiosa & 57 & $49(85.96)$ & $8(14.04)$ \\
Ikorodu & 20 & $20(100)$ & 0 \\
Ojo & 71 & $68(95.77)$ & $3(4.23)$ \\
\hline Fisher exact value $=7.235$, degree of freedom $=4, p$ value $=0.098$ & &
\end{tabular}

Table 4: Distribution of serum samples with protective antibody titre level to Newcastle disease in Lagos State using enzyme linked immunosorbent assay

\begin{tabular}{lccc}
\hline $\begin{array}{l}\text { Local Government } \\
\text { Area }\end{array}$ & $\begin{array}{c}\text { No of } \\
\text { Samples tested }\end{array}$ & $\begin{array}{c}\text { No of samples with } \\
\text { protective antibody titre } \\
\text { level }(\%)\end{array}$ & $\begin{array}{c}\text { No of samples } \\
\text { without protective } \\
\text { Antibody level }(\%)\end{array}$ \\
\hline Badagry & 92 & $92(100)$ & 0 \\
Epe & 24 & $22(91.67)$ & $2(8.33)$ \\
Etiosa & 57 & $57(100)$ & 0 \\
Ikorodu & 20 & $20(100)$ & 0 \\
Ojo & 71 & $71(100)$ & 0 \\
\hline Fijor
\end{tabular}

Fisher exact test value $=8.454$; degree of freedom $=4 ; \mathrm{p}$ value $=0.013$

Table 5: Distribution of samples with protective antibody titre level to Newcastle disease in Lagos state using Haemagglutination inhibition and enzyme linked immunosorbent assay

\begin{tabular}{lccc}
\hline Test & $\begin{array}{c}\text { No of samples with } \\
\text { protective antibody } \\
\text { titre level }(\%)\end{array}$ & $\begin{array}{c}\text { No of samples with } \\
\text { non-protective } \\
\text { antibody level }(\%)\end{array}$ & Total \\
\hline $\begin{array}{l}\text { Haemagglutination } \\
\text { inhibition test }\end{array}$ & $240(90.91)$ & $24(9.09)$ & 264 \\
$\begin{array}{l}\text { Enzyme-linked } \\
\text { immunosorbentassay }\end{array}$ & $262(99.24)$ & $2(0.76)$ & 264 \\
\hline $\mathrm{P}<0.00 ; \mathrm{x}^{2}=19.58$ & & &
\end{tabular}

\section{Discussion}

This study assessed the quality of ND vaccines in Lagos State, Nigeria.The coefficient of variability values obtained from the solubility test on the vaccines in this study could be due to different storage conditions of the vaccines. Vaccines are expected to be stored in a designated refrigerator or freezer with both monitoring and logging of the refrigerators' or freezers' temperature posted on each storage unit door or nearby in a readily accessible and visible location (CDC, 2003). This was not observed during sampling. Power outages generally being witnessed in the country could also be responsible, since both retailers and importers substitute power during outage for specific number of hours in a day (Ambali et al. unpublished).

Office Internationale des Epizootics (OIE) guidelines on vaccine quality criteria, include good manufacturing practice, good labeling practice and good drug use practice (OIE, 2009). Labeling is an important guide for good drug or vaccine use. Some of the vaccines though had important information 


\section{Ambali, Okolocha, Kabir and Moru}

like manufacturing date, expiry date and reconstitution instructions, these information and instructions on some of the vaccines were not in the English language and were not translated despite being registered by National Agency for Food and Drug Administration and Control (NAFDAC). Therefore, at field level the farmer or end users have no opportunity of benefiting from manufacturer's guidelines and instructions on vaccine use. Eventually such users may end up using their discretion or previous experience with other vaccines. This study also revealed that a high percentage of the poultry vaccines especially the imported vaccines $(37.5 \%)$ come with single cock which might have being attributed to loss of negative pressure when subjected to vacuum tests. Majority $(87.5 \%)$ of the small sized $(2 \mathrm{ml})$ category bottles also failed vacuum test which could also be because of the size of the bottle.

The results of antigenicity tests of vaccines obtained in this study shows lower HA titre for foreign vaccines compared to local vaccines (Table 1). This may be due to the time interval between manufacturing and availability at field level, usually resulting from need for extended shipment time. The value of serology in diagnosis is clearly related to the expected immune status of the birds (OIE, 2014). There was no significant variation in the level of antibody seroconversion among the sera tested in different LGAs. The result from the study showed the detection of significantly higher proportion of protective antibody titre in serum samples by ELISA technique compared to HI $\left(p<0.00, x^{2}=19.58\right)$. Thus, ELISA technique proves to be more specific in detecting antibodies against NDV when compared to HI test and this supports the works of Chara et al. (1989), Marquardt et al. (1985), Cadman et al. (1997). HI test detects only antibodies against RBC agglutinating antigens (haemagglutin receptor) while ELISA uses monoclonal antibodies targeting only one epitope. Though, ND ELISA proved a better indicator of immune status than HI. It has been demonstrated by Phillips (1973) that an $\mathrm{HI}$ titre of $5 \log _{2}$ indicates adequate protection against clinical ND. However, according to Gale (1965) birds with no detectable HI could be immune to challenge. Hence significantly high mean $\mathrm{Ab}$ titres up to $11 \log _{2}$ and $120 \mathrm{EU}$ for $\mathrm{HI}$ and ELISA tests respectively, can be as a result of multiple vaccinations of the birds by the farmers or the birds have protective antibodies or could be as a result of repeated exposure of birds to endemic ND through natural infection since they did not show any clinical signs of ND and the farmers did not complain at the time of sampling.

Okeke and Tanimu (1982) also reported that most virus seed for local vaccine production in Nigeria are imported, leading to frequent vaccination failures in the field.

\section{Conclusion}

The study showed that although foreign $\mathrm{vaccines}$ had low er mean Haemagglulination ability than local vaccines despite high usage of the latter, the birds that have been on the vaccines still showed high antibody titre which could be as a result of either multiple use of the vaccines or repeated exposure of birds to endemic Newcastle disease through natural infection.

\section{Conflict of interest}

The authors wish to state that there was no conflict of interest.

\section{References}

Alexander, D.J. 2003. Newcastle disease other avian paramyxoviruses and pneumovirusinfection.In: Diseases of Poultry, Ames:Iowa State 


\section{Quality assessment of commercially available Newcastle disease vaccine}

University Press, 63-99.

Allan, W.H. and Gouph, R.E. 1984. A standard haemagglutination inhibition test for Newcastle disease.1. A comparison of macro and micro methods. Veterinary Records, 95: 120-123.

Cadman, H.F., Kelly, P.J., De Angelis, N.D., Rohde, C. N., Colins and Zulu, T. 1997.Comparison of enzymelinked immunosorbent assay and haemagglutination inhibition test for the detection of antibodies against Newcastle disease virus in ostriches (Struthio camelus), Avian Pathology, 26:357-363.

Centres for Disease Control and P r e vention (C D C) 2003. Guidelines for maintaining and managing the vaccine cold chain. Morbidity and Mortality Weekly Report, 52(42):1023-1025.

Charan, S., Rai, A, and Mahajan, V. M. 1981. Comparison of enzymelinked immunosorbent assay and haemagglutination inhibition test for the detection of Newcastle disease virus antibodies in human sera.Journal Clinical Pathology, 34: 90-92.

Sainsbury, D. (2000). Poultry health and management: chickens, turkeys, ducks, geese and quail (4th ed). Blackwell Science, Oxford.

Ezekiel, C.N., Bandyopadhyay,R., Sulyok, M., Warih, B. and Krska,R. 2012. Fungal and bacterial metabolites in commercial poultry feed from Nigeria. Food Additives and contaminants, 29 (8):1288-1299.

Gale, C., Gard, D. J., Ose, E. E. and Berkman, R. N. 1965. Evaluation of a tissue culture Newcastle disease vaccine. Veterinary Records, 96:213-217.
Marquardt, W., Synder, D. B., Savage, P. K., Kadavil, S. K. and Yancy, F. S. 1985. Antibody response to Newcastle disease virus given by two different routes as measured by ELISA and haemagglutinationinhibition test and associated tracheal immunity. Avian Disease, 29: 71-79.

Nigerian Veterinary Medical Association 2015. Press conference. $R$ e t $r$ i e ved f $r$ o m : http://nvma.org.ng/12-newsand-events/42-nvma-holdspress-conference-on-avianinfluenza.

Ibu, O. J., Aba-Adulugba, A., Adeleke, M. A. and Tijjani, A. Y. 2000. Activity of Newcastle disease and infectious bursal disease viruses in ducks and guinea fowls in Jos area, Nigeria.Sokoto Journal of Veterinary Science, 2: 45-46.

Lagos State Business Directory 2012. Information Supplied by Lagos State Ministry of Commerce and Industry. LSBD, Ikeja, Lagos State. www.lagosstate.gov.ng.

Office International Des Epizooties (OIE) 1992. Newcastle. In: Manual for Animal Disease.Reporting to the World Organization for Animal Health, Paris.

Office International des Epizooties (OIE) 2008. Infectious bursa disease (Gumboro disease). In: Manual of Diagnostic Tests and Vaccines for Terrestrial Animals. Pp. 549-565.

Office International Des Epizooties (OIE) 2009. Manual for Diagnostic Tests and Vaccines for TerrestialAnimals.www.oie:int.

Office International des Epizooties (OIE), 2012. Terrestrial manual list of tests for international trade, XI- 


\section{Ambali, Okolocha, Kabir and Moru}

XIV.

Office International Des Epizooties (OIE) 2014. Standard for management and Technical Requirement for Laboratory Conducting Test for Infectious AnimalDisease.International Animal Health Code. World Organization for Animal Health, Paris. www.oie, int/0807/2014

Ogundele, F. O. 2012. Variation in the Physico-chemical Properties of Badagry and Ikorudu Soils, Lagos Nigeria.

Okeke, E. N and Lamorde, A. G. 1988. Newcastle disease and its control in Nigeria," in Viral Disease of Animals in Africa, A.O.Williams and W. N. Masiga, Eds., CTA/OAU/STRC/ Publication, Lagos, Nigeria.

Okeke,E.N and Tanimu,T.1982. Development and production of infectious bursal disease (Gumboro) vaccine in Nigeria. Nigerian Journal of Animal Production, 80-89.

Pastoret, P.P., Blancau, O.U., Vannier, P. and Verschueren, C. 1997 (eds.).Veterinary Vaccinology. Amsterdam ; New York : Elsevier Science, 208-212.

Phillips, J.M. 1973. Vaccination against Newcastle disease, an assessment of haemagglutination inhibition titres obtained from field samples. Veterinary Record 93:577-583.

Aliyu, H.B.,Sa'idu, L.,Abdu, P.A. and Ol ad ele, S.B. 2015. Retrospective Analysis of Newcastle disease diagnosed at the Poultry Clinic of Ahmadu Bello University, Zaria, Nigeria. Sokoto Journal of Veterinary Sciences, 13(3): 42-48.

Aliyu, H.B., Sa'idu, L., Abdu, P.A. and
Oladele, S.B. 2016.Humoral Immune Response of Chickens Following Vaccination with different Newcastle Disease Vaccines. Nigerian Veterinary Journal, 37(2): 102-108.ale, C., Gard, D.J., Ose, E.E and Berkman, R.N. 1965.Evaluation of a tissue culture Newcastle disease vaccine. Veterinary Records, 96:213-217.

Marquardt, W .W.,Synder, D.B., Savage, P.K., Kadavil, S.K. and Yancy, F.S. 1985. Antibody response to Newcastle disease virus given by two different routes as measured by ELISA and haemagglutination-inhibition test and associated tracheal immunity. Avian Disease, 29: 71-79.

Nigerian Veterinary Medical Association 2015. Press conference. Retrieved from: http://nvma.org.ng/12-newsand-events/42-nvma-holds-pressconference-on-avian-influenza.

Ibu, O. J. Aba-Adulugba, A., Adeleke, M.A. and Tijjani, A.Y. 2000. Activity of Newcastle disease and infectious bursal disease viruses in ducks and guinea fowls in Jos area, Nigeria.Sokoto Journal of Veterinary Science, 2: 45-46.

Lagos State Business Directory 2012. Information Supplied by Lagos State Ministry of Commerce and Industry. LSBD, Ikeja, Lagos State. www.lagosstate.gov.ng.

Office International Des Epizooties (OIE) 1992. Newcastle. In: Manual for Animal Disease.Reporting to the World Organization for Animal Health, Paris.

Office International des Epizooties (OIE) 2008. Infectious bursa disease(Gumboro disease). In: 
Quality assessment of commercially available Newcastle disease vaccine

Manual of Diagnostic Tests and Vaccines for Terrestrial Animals. Pp. 549-565.

Office International Des Epizooties (OIE) 2009. Manual for Diagnostic Tests and Vaccines for TerrestialAnimals.www.oie:int.

Office International des Epizooties (OIE), 2012. Terrestrial manual list of tests for international trade, XIXIV.

Office International Des Epizooties (OIE) 2014.Standard for management and Technical Requirement for Laboratory Conducting Test for Infectious AnimalDisease.International Animal Health Code. World Organization for Animal Health, Paris. www.oie, int $/ 0807 / 2014$

Ogundele, F. O. 2012. Variation in the Physico-chemical Properties of Badagry and Ikorudu Soils, Lagos Nigeria.

Okeke, E. N. and Lamorde, A. G. 1988. Newcastle disease and its control in Nigeria," in Viral Disease of Animals in Africa, A.O.Williams and W. N. Masiga, Eds., CTA/OAU/STRC/ Publication, Lagos, Nigeria.

Okeke, E. N. and Tanimu, T. 1982. Development and production of infectious bursal disease (Gumboro) vaccine in Nigeria. Nigerian Journal of Animal Production,80-89.
Pastoret, P. P., Blancau, O. U., Vannier, P. and Verschueren, C. 1997 (eds.). Veterinary Vaccinology. Amsterdam; New York: Elsevier Science, 208-212.

Phillips, J. M. 1973. Vaccination against Newcastle disease, an assessment of haemagglutination inhibition titres obtained from field samples. Veterinary Record 93:577-583.

Aliyu, H. B., Sa'idu, L., Abdu, P. A. and Oladele, S. B. 2015. Retrospective Analysis of Newcastle disease diagnosed at the Poultry Clinic of Ahmadu Bello University, Zaria, Nigeria. Sokoto Journal of Veterinary Sciences, 13(3): 42-48.

Aliyu, H. B., Sa'idu, L., Abdu, P. A. and Oladele, S. B. 2016. Humoral Immune Response of Chickens Following Vaccination with different Newcastle Disease Vaccines. Nigerian Veterinary Journal, 37(2): 102-108.

Received: $12^{\text {th }}$ August, 2018

Accepted: $9^{\text {th }}$ February, 2019 